\section{Heroes and villains}

\section{Marian Stamp Dawkins}

\section{Animal Revolution: Changing Attitudes Towards Speciesism. By Richard D. Ryder. Basil Blackwell: 1989. Pp.385. $£ 17.50, \$ 24.95$}

RICHARD Ryder has the distinction of having introduced a new word - speciesism - into the English language. In 1975, he used it to describe "the widespread discrimination that is practiced by man against other species, and to draw a parallel between it and racism" (Victims of Science, p.16). In his latest book, Animal Revolution, he describes the history of this idea from the ancient Egyptians to the present day.

Ryder gives an unashamedly personal view of the way humans treat animals. For the first half of the book, the fact that Ryder has strong views of his own adds to rather than detracts from the book's impact. He gives spice to his history by describing his heroes, such as St Neot, who was evidently one of the earliest hunt saboteurs, and villains such as Robert Baden-Powell, who described pig-stiicking or hog-hunting as "manly and tip-top" (p.134). The reader can quite easily take the first ten chapters as one man's view of history, without necessarily agreeing with every word. Only the odd gratuitous swipe at the Royal Society for the Protection of Cruelty to Animals (RSPCA) mars an otherwise fascinating narrative, full of gems and nuggets of information. There are some excellent tales, too, such as Queen Victoria's behind-the-scenes support of the 1876 legislation on animal experiments and a somewhat spinechilling quotation from George Bernard Shaw (p.132). Shaw wrote provocatively: "No sportsman wants to kill the fox or the pheasant as I want to kill him when I see him doing it."

In turning from history to the present day, however, Ryder's own views become rather more intrusive. There is a fairly large section on the internal squabbles that took place within the RSPCA and his own role in them. This is 'dirty linen' history of a not very illuminating sort. The RSPCA is an important animal-welfare organization, but seen against the backdrop of the history of human attitudes to non-human animals, its private difficulties and what Ryder himself did to resolve them are surely not worth reporting in such detail.

There then follow substantial chapters on three key issues of animal welfare wildlife conservation, animal experimentation and farming. Here, too, Ryder's views are intrusive to the point of distor- tion. He pulls no punches about scientists and vivisectors and their motives: "once they have been 'bloodied' they have a psychological vested interest in continuing their trade" (p.253). Nor does he conceal his contempt for many scientists and veterinarians and what they do to animals.

In describing modern farming methods, Ryder marshals some disturbing statistics about current practices, but he gives the impression that the issues are far more clear-cut than they really are. Many people will agree with him that there is a lot that should be changed about the way animals are kept on farms, but there are difficulties with abandoning current practices - such as the cannibalism and feather-pecking that are such a worrying feature of some commercial free-range and perchery systems for laying hens. By not even mentioning such problems and making it sound as though 'alternatives' to intensive systems are always, without question, better for animal welfare, Ryder weakens the very case he is trying to make.

It is, however, in the chapter called "Violence and the Animal Liberation Front" that Ryder is perhaps at his most controversial. He argues that violence against front members is actually more prevalent than violence by them and that to call them terrorists is a deliberate slur. As evidence that animal liberationists are in danger because of their beliefs, he cites cases of hunt saboteurs being attacked by huntsmen, the sinking of the Greenpeace flagship Rainbow Warrior and the murder of Dian Fossey.

Throughout the book, Ryder re-affirms his belief that speciesism is a moral wrong on a par with racism. His position is, as he describes it (p.8), the "startlingly simple" one that "whatever is morally wrong in the human case is probably wrong in the non-human case as well". I found it disappointing that some of the serious and thoughtful critics of this view, such as Bernard Williams, are not mentioned. Anti-speciesism is an important idea but, paradoxically, the case for it could have been made more persuasively if more time had been given to discussing the genuine difficulties with it.

The way humans treat non-human animals is a matter of great importance, but to many people issues such as whether we should eat animals or do experiments on them are not "startlingly simple" but difficult in the extreme. One man's view of these matters, which is what Ryder's book is, will appeal to some, but probably fail to convince those for whom the moral issues are more complex.

Marian Stamp Dawkins is in the Animal Behaviour Research Group, Department of Zoology, University of Oxford, South Parks Road, Oxford OX1 3P5, UK.

\section{Mixed metaphor}

\author{
Sandra Panem
}

Shattered Mirrors: Our Search for Identity and Community in the AIDS Era. By Monroe E. Price. Harvard University Press: 1989 Pp. 159. \$19.95, £15.95.

DESPITE the global scope of AIDS, the analytical response to the epidemic has been in many ways a highly nationalistic and peculiarly American phenomenon. AIDS has as frequently been used as a vehicle to expose problems in US society as it has been to discuss the particular problems of the disease. The "American interpretation" of AIDS reflects the early emergence of the epidemic in the United States, the global dominance of the US biomedical establishment, and the predominant place that AIDS has had on the US socio-political agenda. During the past decade, AIDS has become a metaphor for a troubled American society.

Monroe Price's Shattered Mirrors is the newest entry in this parochial genre. Price's comments are focused through the distinctive American lens of the constitutional scholar. In a highly readable, and mercifully terse essay, the dilemmas raised by AIDS are seen to derive from the most basic tenants of US law. Price, Dean of the Benjamin N. Cardozo School of Law at Yeshiva University, clearly understands and documents what others know only instinctively.

AIDS is the first national text in a great while that even purports to address the propriety of adult behaviour... [there] ... is a new focus on what the individual does, not just the heroic individual, or the researcher in the laboratory, but the ordinary person, the parent, the single adult, the adolescent child. All of a sudden, in the national consciousness, what the individual does is meaningful in terms of something larger, something connected to the fate of the community.

Price's interest seems to lie in the changing balance between policies that protect society at the expense of individual liberty and those that favour individualism. He cogently explains why this choice is especially hard in the United States, bolstering his argument with extensive reference to case and common law.

Students of the AIDS epidemic will find issues in Price's book that have not been raised before. Yet even when treading on all-too-familiar ground, Price brings an interesting interpretation. Take, for example, his handling of a complaint commonly heard early in the epidemic - that had the first afflicted group been more mainstream, the response to AIDS would have been very different:

Ours is, for better or for worse, a society that presumes, indeed thrives on inequities that arise not out of the denial of opportunity itself 